\title{
PERANCANGAN CURRENT LIMITER SEBAGAI PROTEKSI SISTEM CHARGING BATERAI
}

\author{
Jessy Kris Dayanti*), Trias Andromeda dan Yuli Christyono \\ Departemen Teknik Elektro, Universitas Diponegoro \\ Jl. Prof. Sudharto, SH, Kampus UNDIP Tembalang, Semarang 50275, Indonesia \\ ${ }^{*}$ E-mail: jessykris95@gmail.com
}

\begin{abstract}
Abstrak
Sistem proteksi overcurrent sangat penting dalam sistem Hybrid Charger Controller terutama untuk melindungi catu daya yang terhubung dengan beban. Penggunaan beban yang besar dan saat terjadi hubung singkat mengakibatkan overcurrent yang dapat merusak perangkat pada sistem Hybrid Charger Controler. Salah satu alat proteksi overcurrent adalah current limiter. Current limiter berfungsi untuk membatasi arus beban sesuai dengan yang dirancang saat terjadi overcurrent dan hubung singkat. Kelebihan rangkaian current limiter yaitu mampu bekerja lebih cepat, lebih sederahana dan lebih ekonomis karena hanya menggunakan komponen bipolar junction transistor dan resistor. Pada Penelitian ini penulis merancang penerapan current limiter sebagai proteksi overcurrent pada sistem Hybrid Charger Controller. Pada Penelitian ini dilakukan tiga pengujian pada current limiter yang dibuat, yaitu pengujian arus keluaran kondisi normal, kondisi overcurrent dengan menggunakan variasi nilai beban resistor murni dan hubung singkat. Pengujian kondisi normal besar nilai arus yang dihasilkan berdasarkan besar nilai beban resistor. Pengujian kondisi overcurrent dan hubung singkat besar nilai arus keluaran yang dihasilkan oleh current limiter untuk beban $5 \mathrm{~V}_{\mathrm{DC}}$ sebesar $0,23 \mathrm{~A}$ dan untuk beban $12 \mathrm{~V}_{\mathrm{DC}}$ sebesar 0,45 A.
\end{abstract}

Kata kunci : Proteksi Overcurrent, Current limiter, Hybrid Charger Controller

\begin{abstract}
Overcurrent protection system is very important in the Hybrid Charger Controller system mainly to protect the power supply connected to the load. The use of a large load and when it occurs for excess current that can be used in the Hybrid Charger Controler system. One of the overcurrent protection devices is the current limiter. The current limit works to reflect the load in accordance with the one designed when there is overcurrent and short circuit. The advantage of the current limiter circuit is that it is able to work faster, more easily and more economically because it only uses the bipolar junction transistor and resistor components. In this Research the author uses a current limiter as overcurrent protection on the Hybrid Charger Controller system. In this final project, three parameters are made on the current limiting that is made, namely testing the normal conditions, overcurrent conditions using pure resistor load values and short circuit. Normal conditions large current values generated. Examination of excess current and short circuit large current value Output generated by current limiter for load $5 \mathrm{VDC}$ is $0,23 \mathrm{~A}$ and for load $12 \mathrm{VDC}$ is $0,45 \mathrm{~A}$.
\end{abstract}

Keywords: Overcurrent protection, Current limiter, Hybrid Charger Controller

\section{Pendahuluan}

Kebanyakan peralatan-perlatan catu daya modern memiliki sistem proteksi overcurrent untuk melindungi rangkaian catu daya tersebut dari arus lebih yang disebabkan oleh beban yang berlebih. Namun demikian, sistem proteksi overcurrent pada rangkaian catu daya modern masih banyak yang menggunakan komponen yang seperti fuse dan relai karena tegangan catu daya yang berubah-ubah. Pada sistem Hybrid Charger Controller catu daya yang digunakan memiliki tegangan keluaran yang konstan yaitu dari baterai sebesar $12 \mathrm{~V}$ dan konverter synchronous buck sebesar $5 \mathrm{~V}$. Sebagai jawaban terhadap masalah tersebut adalah dengan diimplementasikannya sistem proteksi overcurrent yang berupa rangkaian current limiter dengan menggunakan resistor current sense dan Bipolar Junction Transistor (BJT) karena pada sistem Hybrid Charger Controller ini tegangan suplai beban tidak berubah-ubah. Current limiter dibuat untuk menciptakan sistem proteksi overcurrent yang lebih sederhana, mampu bekerja secara cepat dan lebih ekonomis, saat terjadi overcurrent akibat overload maupun hubung singkat.

Pembatas Arus Elektronik (elektronic fuse) digunakan di dalam sistem mikrosatelit berbasis komponen yang siap di pasaran (Commercial off the Shelf) dan dirancang memiliki keluwesan (flexibillity) yang tinggi serta hasil rancangan menunjukkan bahwa rangkaian pembatas arus dapat 
membatasi arus masing-masing perangkat sebesar 0,834 dan 1.833 Ampere[1]. Foldback current limiter bergerak sebagai respon terhadap arus yang ditarik oleh beban ketika ambang batas current limiter terlampaui[2]. Current limiter untuk switching catu daya regulator menjelaskan bahwa rangkaian tersebut sebagai sarana sensing arus yang melalui swtching transistor dengan menggunakan resistor current sense[3].

Rangkaian current limiter menggunakan dua transistor yang dikonfigurasikan sebagai pasangan diferensial, dikombinasikan dengan sumber arus tetap untuk membatasi arus yang tersedia ke transistor pass dari regulator tegangan[4]. Current limiter sangat berguna sebagai fitur keamanan dalam peralatan pengujian medis atau sejenisnya. Rangkaian tersebut terdiri dari transistor efek medan yang digabungkan secara seri dengan transistor efek medan pusat yang terbias menjadi konduksi. Transistor medan efek pusat lainnya digunakan untuk mengontrol teganagn drop yang melalui transistor efek medan pusat untuk konduksi[5].

\section{Metode}

\subsection{Perancangan Perangkat Keras}

Perangcangan ini terdiri dari dua buah current limiter dengan batas masing-masing 0,25 A untuk beban $5 \mathrm{~V}$ dan 0,5 A untuk beban $12 \mathrm{~V}$, berikut diagram blok skema secara keseluruhan perangkat keras current limiter pada sistem Hybrid Charger Controller dapat dilihat pada Gambar 1.

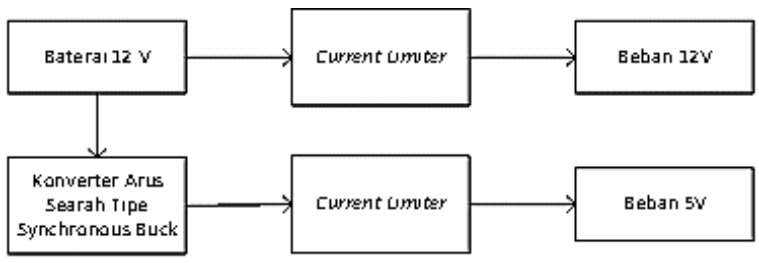

Gambar 1. Blok Diagram Alat

\subsection{Current limiter}

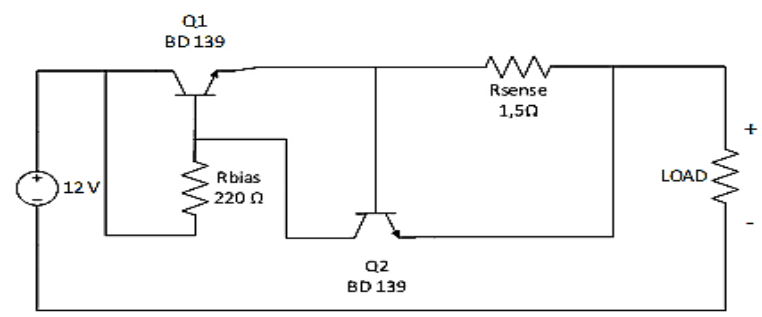

Gambar 2. Rangkaian current limiter

Gambar 2 merupakan rangkaian current limiter pada Penelitian ini tersusun dari komponen-komponen berikut:

1. Sumber Tegangan DC $\left(V_{i n}\right)$

Sumber tegangan yang digunakan sebagai suplai tegangan current limiter yang terhubung beban.

2. Bipolar Junction Transistor

Pada Current limiter ini, digunakan BJT tipe NPN sebagai komponen pensaklaran. BJT tipe NPN BD139 yang berfungsi sebagai saklar untuk membatasi arus.

3. Resistor

Resistor yang digunakan berfungsi untuk menghambat arus. Perhitungan resistor pada current limiter berdasarkan aliran arus dan hukum khirchoff tegangan. menggunakan persamaan hukum ohm sebagai berikut

\subsection{Realisasi Rangkaian Current limiter}

Pada peneletian ini, current limiter dibuat dengan menggunakan dua transistor dan resistor. Berikut perhitungan komponen current limiter.

\subsubsection{Bipolar Junction Transistor}

Pada current limiter ini, digunakan BJT tipe NPN sebagai komponen pensaklaran. BJT tipe NPN BD139 beroperasi dengan tegangan kolektor emiter saturasi (VCEsat) maksimal $0,5 \mathrm{~V}$ serta memiliki tegangan basis emiter (VBE) 0,7V dan arus kolektor (IC) maksimal 1,5A [12]. Current limiter membatasi arus beban $12 \mathrm{~V}$ sebesar 0,5A yang sumber tegangannya berasal dari baterai 12V. Selain tegangan masukan DC dari baterai, current limiter dengan batas 0,25A mendapat tegangan masukan dari konverter arus searah tipe Synchronous Buck sebesar 5V .

Arus DC maksimum BJT tipe NPN BD139 sebesar 1,5 A dinilai cukup aman dalam menahan arus sesuai dengan batas arus current limiter yang dirancang yaitu sebesar $0,5 \mathrm{~A}$ untuk beban $12 \mathrm{~V}$ dan $0,25 \mathrm{~A}$ untuk beban $5 \mathrm{~V}$.

DC Current Gain $\left(\mathrm{h}_{\mathrm{FE}}\right)$ atau penguatan arus yang disimbolkan dengan $\beta$ adalah konstanta untuk suatu transistor, dimana besar $\beta$ merupakan perbandingan antara nilai $I_{c}$ dan nilai $I_{b}$ biasanya berharga sekitar $100-200$. Besar nilai $\beta$ dapat dilihat pada datasheet transistor. Pada rangkaian current limiter besar nilai $\beta$ digunakan untuk mencari besar margin atau batas arus $I_{\mathrm{b}}$ yang mengalir ke basis BJT BD139 untuk mengatur besar arus kolektor $I_{c}$ yang megalir menuju beban. Sehingga didapat perhitungan sebagai berikut.

a.) Current limiter untuk beban $12 \mathrm{~V}$ batas $0,5 \mathrm{~A}$

$\beta=\frac{I_{c}}{I_{b}}$

$25=\frac{500 m A}{I b}$

$I b=\frac{500 m A}{25}$

$I b=20 \mathrm{~mA}$

Untuk mengaktifkan transistor $\mathrm{Q}_{2}$ maka memerlukan arus dua hingga tiga kali lipat dari besar arus $\mathrm{I}_{\mathrm{b}}$ transistor $\mathrm{Q}_{1}$ sehingga margin $\mathrm{I}_{\mathrm{b}}$ yang digunakan sebesar $50 \mathrm{~mA}$.

b.) Current limiter untuk beban $5 \mathrm{~V}_{\mathrm{DC}}$ batas $0,25 \mathrm{~A}$ 


$$
\begin{aligned}
\beta & =\frac{I_{C}}{I_{b}} \\
95 & =\frac{200 \mathrm{~mA}}{I b} \\
I b & =\frac{200 \mathrm{~mA}}{95} \\
I b & =2,6 \mathrm{~mA}
\end{aligned}
$$

Untuk mengaktifkan transistor $\mathrm{Q}_{2}$ maka memerlukan arus dua hingga tiga kali lipat dari besar arus $\mathrm{I}_{\mathrm{b}}$ transistor $\mathrm{Q}_{1}$ sehingga margin $\mathrm{I}_{\mathrm{b}}$ yang digunakan sebesar $6 \mathrm{~mA}$.

$$
\begin{array}{ll}
\text { Keterangan : } & \\
\beta & : \text { DC Current Gain }\left(h_{F E}\right) \\
I_{b} & : \text { Arus Base }(\mathrm{mA}) \\
I_{c} & : \text { Arus Collector }(\mathrm{mA})
\end{array}
$$

Pada perancangan current limiter ini juga mempertimbangkan total disispasi daya transistor, yaitu daya berupa panas yang terbuang sia-sia. Disipasi daya ini akan merusak transistor bila terlalu berlebihan, oleh sebab itu transistor diberi pembenaman panas berupa (heatsink). Berikut perhitungan total disipasi daya pada perangkat current limiter ini [9]

Untuk current limiter beban $12 \mathrm{~V}$ batas $0,5 \mathrm{~A}$, memiliki nilai $\mathrm{I}_{\mathrm{b}} 50 \mathrm{~mA}$ dan $\mathrm{V}_{\text {CEsat }} 0,5 \mathrm{~V}$, maka dapat dihitung nilai maksimum disipasi daya transistor sebagai berikut.

$\mathrm{P}_{\text {tot }}=P_{B}+P_{C}+P_{\text {load }}$

$\mathrm{P}_{\text {tot }}=I_{b} V_{B E}+I_{C} V_{\text {CEsat }}+\left(V_{\text {in }}-V_{B e}\right) I_{C}$

$\mathrm{P}_{\text {tot }}=0,05.0,7+0,5 \cdot 0,5+(12-0,7) 0,5$

$\mathrm{P}_{\text {tot }}=0,035+0,25+5,65$

$\mathrm{P}_{\mathrm{tot}}=5,935 \mathrm{Watt}$

Untuk current limiter beban $5 \mathrm{~V}$ batas $0,25 \mathrm{~A}$, memiliki nilai $\mathrm{I}_{\mathrm{b}} 6 \mathrm{~mA}$ dan $\mathrm{V}_{\text {CEsat }} 0,12 \mathrm{~V}$, maka dapat dihitung nilai maksimum disipasi daya transistor sebagai berikut.

$$
\begin{aligned}
& \mathrm{P}_{\text {tot }}=P_{B}+P_{C} \\
& \mathrm{P}_{\text {tot }}=I_{b} V_{B E}+I_{C} V_{C E s a t}+\left(V_{\text {in }}-V_{B e}\right) I_{C} \\
& \mathrm{P}_{\text {tot }}=0,006.0,7+0,25.0,5+(5-0,7) 0,25 \\
& \mathrm{P}_{\text {tot }}=0,0042+0,125+1,075 \\
& \mathrm{P}_{\text {tot }}=1,205 \text { Watt }
\end{aligned}
$$

\section{Keterangan :}

$\begin{array}{ll}P_{\text {tot }} & \text { : Disipasi daya total (Watt) } \\ P_{B} & \text { : Disipasi daya base emiter (Watt) } \\ P_{C} & \text { : Disipasi daya base emiter (Watt) } \\ P_{\text {Load }} & \text { : Disipasi daya beban (Watt) }\end{array}$

Dari perhitungan diatas maka penggunaan BJT NPN BD139 sebagai komponen aktif pada current limiter sudah tepat karena nilai disipasi daya yang digunakan harus kurang dari nilai disipasi daya yang tertera agar transisor tidak rusak akibat panas yang berlebih.

\subsubsection{Resistor}

Dalam kondisi normal dimana transistor $\mathrm{Q}_{1}$ on dan transistor $\mathrm{Q}_{2}$ off , maka didapat aliran arus input yaitu arus saat transistor off dan arus output yaitu dimana saat transistor on pada $\mathrm{Q}_{1}$. Untuk mengaktifkan transistor membutuhkan tegangan $V_{B E}$ sebesar $0,7 \mathrm{~V}$ karena berbahan silikon dan tegangan input pada rangkaian tersebut sebesar $12 \mathrm{~V}$ serta nilai $\mathrm{I}_{\mathrm{b}}$ sebesar $50 \mathrm{~mA}$. Dengan menggunakan hukum kirchoff tegangan maka didapat perhitungan sebagai berikut [9].

$$
\begin{aligned}
& V_{\text {in }}-I_{b} R_{\text {bias }}-V_{B E}=0 \\
& R_{\text {bias }}=\frac{V_{\text {in }}-V_{B E}}{I_{b}} \\
& R_{\text {bias }}=\frac{12-0,7 V}{0,05 \mathrm{~A}} \\
& R_{\text {bias }}=226 \Omega
\end{aligned}
$$

Untuk membuat arus Ic lebih besar dari 0,5A dan mempertimbangakan ketersediaan resistor dipasaran, maka resistor yang digunakan bernilai $220 \Omega$.

Sedangkan untuk current limiter beban $5 \mathrm{~V}$ dengan batas 0,25 A dapat menggunakan rumus yang sama, dan nilai $\mathrm{I}_{\mathrm{b}}$ sebsar $6 \mathrm{~mA}$ maka didapat perhitungan $\mathrm{R}_{\text {bias }}$ sebagai berikut.

$$
\begin{aligned}
& V_{\text {in }}-I_{b} R_{\text {bias }}-V_{B E}=0 \\
& R_{\text {bias }}=\frac{V_{\text {in }}-V_{B E}}{I_{b}} \\
& R_{\text {bias }}=\frac{5-0,7 \mathrm{~V}}{0,006 \mathrm{~A}} \\
& R_{\text {bias }}=716 \Omega
\end{aligned}
$$

Untuk membuat arus $\mathrm{I}_{c}$ lebih besar dari 0,25A dan mempertimbangakan ketersediaan resistor dipasaran, maka resistor yang digunakan bernilai $680 \Omega$.

Pada rangkaian current limiter terdapat resistor yang berfungsi sebagai current sense (Rsense) yaitu memonitor arus $\mathrm{I}_{\mathrm{c}}$ saat terjadi overcurrent yang melewati transistor $\mathrm{Q}_{1}$ dan membuat transistor $\mathrm{Q}_{2}$ on karena tegangan drop pada $\mathrm{R}_{\text {sense }}$ sama besarnya dengan tegangan $\mathrm{V}_{\mathrm{BE}}$ transistor $\mathrm{Q}_{2}$ yaitu $0.7 \mathrm{~V}$.

Saat kondisi overcurrent, transistor $\mathrm{Q}_{1}$ belum sepenuhnya dalam keadaan cut off atau full off ketika arus $\mathrm{I}_{\mathrm{c}}$ yang besar melebihi nilai 0,5 A sehingga arus Ic masih mengalir menuju $R_{\text {sense }}$ maka tegangan dititik antara basis $Q_{2}$ dan $\mathrm{R}_{\text {sense }}$ bernilai lebih dari $0,7 \mathrm{~V}$. Hal ini membuat transistor $\mathrm{Q}_{2}$ on dan transistor $\mathrm{Q}_{1}$ off sehingga beberapa arus $\mathrm{I}_{\mathrm{c}}$ akan mengalir dari kolektor transistor $\mathrm{Q}_{2}$ melalui $\mathrm{R}_{\text {bias }}$ dan dialihkan ke ground serta menjaga tegangan basis transistor $\mathrm{Q}_{2}$ kurang dari $0,7 \mathrm{~V}$. Setelah tegangan pada titik antara basis transistor $\mathrm{Q}_{2}$ dan $\mathrm{R}_{\text {sense }}$ kurang dari 0,7 V maka current limiter akan kembali bekerja normal dimana transistor $\mathrm{Q}_{1}$ on dan transistor $\mathrm{Q}_{2}$ off. Nilai Rsense dapat dihitung sebagai berikut.

$R_{\text {sense }}=\frac{V_{B E Q 2}}{I_{C}}$ 


$$
\begin{aligned}
& R_{\text {sense }}=\frac{0,7 \mathrm{~V}}{0,5 \mathrm{~A}} \\
& R_{\text {sense }}=1,4 \Omega
\end{aligned}
$$

Keterangan :

$R_{\text {sense }} \quad$ : Resistor current sense $(\Omega)$

$V_{B E Q 2} \quad$ : Tegangan basis emiter $(\mathrm{V})$

$I_{C} \quad:$ Arus kolektor (A)

Untuk keamanan pengguna serta perangkat dan ketersediaan resistor dipasaran maka pada rangkaian current limiter untuk beban $12 \mathrm{~V}$ batas $0,5 \mathrm{~A}$ menggunakan resistor sebesar $1,5 \Omega$. Karena arus yang mengalir pada $\mathrm{R}_{\text {sense }}$ cukup besar maka harus mempertimbangkan daya pada resistor tersebut.

Resistor memiliki batas kemampuan daya yang berarti resistor hanya dapat dioperasikan dengan daya maksimal sesuai dengan kemampuan dayanya. Pada resistor current sense ini pemilihan daya resistor sangat penting agar resistor mampu menahan panas dari arus yang dihasilkan beban saat overcurrent maupun hubung singkat sehingga resistor tidak terbakar dan current limiter dapat bekerja sesuai dengan fungsinya.

Untuk besar arus $0,5 \mathrm{~A}$ dan nilai $\mathrm{R}_{\text {sense }} 1,5 \Omega$ maka didapat perhitungan daya pada resistor sebagai berikut.

$P=I_{c}{ }^{2} R_{\text {sense }}$

$P=0,5^{2} \cdot 1,5$

$P=0,375$ Watt

Keterangan :

$\mathrm{P} \quad$ : Daya resistor (Watt)

$R_{\text {sense }} \quad:$ Resistor current sense $(\Omega)$

$I_{c} \quad:$ Arus kolektor (A)

Untuk menghindari panas yang berlebih dan kerusakan pada resistor maka digunakan resistor dengan daya 5 Watt. Sedangkan untuk rangkaian current limiter beban $5 \mathrm{~V}$ batas 0,25 A besar nilai $R_{\text {sense }}$ dengan rumus yang sama dapat dihitung sebagai berikut.

$R_{\text {sense }}=\frac{V_{B E Q 2}}{I_{C}}$

$R_{\text {sense }}=\frac{0.7 \mathrm{~V}}{0,3 \mathrm{~A}}$

$R_{\text {sense }}=2,8 \Omega$

Untuk keamanan pengguna serta perangkat dan ketersediaan resistor dipasaran maka pada rangkaian current limiter untuk beban $5 \mathrm{~V}$ batas $0,25 \mathrm{~A}$ menggunakan resistor sebesar $2,7 \Omega$. Karena arus yang mengalir pada $\mathrm{R}_{\text {sense }}$ cukup besar maka harus mempertimbangkan daya pada resistor tersebut. Untuk besar arus $0,25 \mathrm{~A}$ dan nilai $\mathrm{R}_{\text {sense }} 3,3 \Omega$ maka didapat perhitungan daya pada resistor sebagai berikut.
$P=I_{c}^{2} R_{\text {sense }}$

$P=0,25^{2} \cdot 3,3$

$P=0,206$ Watt

Untuk menghindari panas yang berlebih dan kerusakan pada resistor maka digunakan resistor dengan daya 5 Watt. Untuk mencari nilai beban minimum $\mathrm{R}_{\text {load }}$ dalam kondisi normal maka dapat dihitung dengan persamaan hukum kirchoff tegangan berdasarkan aliran arus output transistor $\mathrm{Q}_{1}$

Diketahui nilai $\mathrm{V}_{\text {CEsat }}$ saat $\mathrm{I}_{\mathrm{C}}$ sama dengan 0,5 A sebesar $0,5 \mathrm{~V}$ [12] dan maka didapat hasil perhitungan sebagai berikut.

a.) Current limiter untuk beban $12 \mathrm{~V}_{\mathrm{DC}}$ batas $0,5 \mathrm{~A}$

$V_{\text {in }}-V_{C E(\text { sat })}-I_{c} R_{\text {sense }}-I_{c} R_{\text {load }}=0$

$12-0,5-0,5.1,5-0,5 R_{\text {load }}=0$

$0,5 R_{\text {load }}=12-0,5-0,5.1,5$

$0,5 R_{\text {load }}=10,75 \mathrm{~V}$

$R_{\text {load }}=\frac{10,75 \mathrm{~V}}{0,5 \mathrm{~A}}$

$R_{\text {load }}=21.5 \Omega$

Sedangkan untuk current limiter batas 0,25 A memiliki nilai $\mathrm{V}_{\text {CEsat }}$ sebesar $120 \mathrm{mV}$ [12] maka didapat hasil perhitungan sebagai berikut.

b.) Current limiter untuk beban $5 \mathrm{~V}_{\mathrm{DC}}$ batas $0,25 \mathrm{~A}$

$V_{\text {in }}-V_{C E(\text { sat })}-I_{c} R_{\text {sense }}-I_{c} R_{\text {load }}=0$

$5-0,12-0,25.3,3-0,25 R_{\text {load }}=0$

$0,25 R_{\text {load }}=5-0,12-0,25.3,3$

$0,25 R_{\text {load }}=4,055 \mathrm{~V}$

$R_{\text {load }}=\frac{4,055 \mathrm{~V}}{0,25 \mathrm{~A}}$

$R_{\text {load }}=16,22 \Omega$

Keterangan :

$V_{D C} \quad:$ Tegangan input $(\mathrm{V})$

Ic $\quad$ : Batas arus current limiter $(\mathrm{A})$

$R_{L} \quad$ : Resistor beban (Ohm)

Dari perhitungan nilai beban $\mathrm{R}_{\text {load }}$ minimum saat kondisi normal untuk beban $12 \mathrm{~V}$ sebesar $22 \Omega$ dan untuk beban $5 \mathrm{~V}$ sebesar $18 \Omega$.

Berikut ini adalah realisasi rangkaian current limiter dengan batas arus 0,5 A dan 0,25 A yang ditunjukkan pada Gambar 3. 


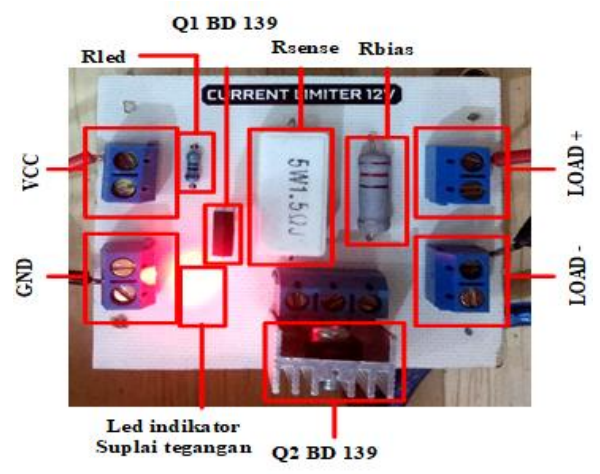

(a)

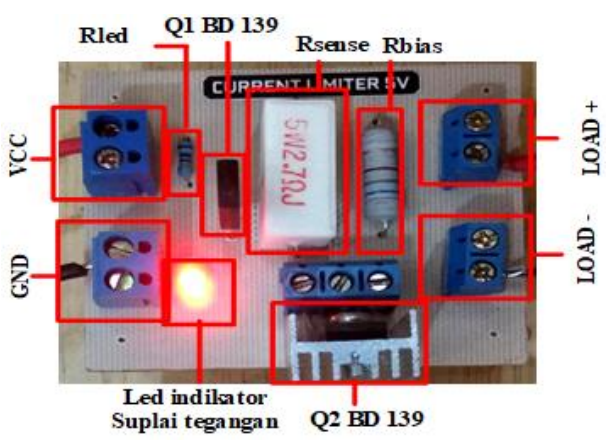

(b)

Gambar 3. (a) Realisasi Current limiter beban $12 \mathrm{~V}$ batas 0,5 A

(b) Realisasi Current limiter beban $5 \mathrm{~V}$ batas 0,25 A

\section{Hasil dan Analisa}

\subsection{Pengujian Arus Keluaran Kondisi Normal}

Pada pengujian ini, data diambil dengan menggunakan beban berupa resistor murni yang memiliki nilai lebih besar dari $18 \Omega$ untuk current limiter dengan batas 0,25 A dan resistor dengan nilai lebih besar dari $20 \Omega$ untuk current limiter dengan batas 0,5 A. Arus keluaran current limiter diukur menggunakan multimeter DM-133D dengan probe arus dihubung seri dengan beban resistor murni.

Tabel 1. Data Current limiter batas 0,25 A kondisi normal

\begin{tabular}{ccccc}
\hline No & Beban $R(\Omega)$ & Tegangan $(\mathrm{V})$ & lukur $^{2}$ & Arus $(\mathrm{A})$ \\
\hline 1 & 18,2 & 5,05 & 0,14 & 0,28 \\
2 & 27 & 5,05 & 0,11 & 0,19 \\
3 & 39 & 5,05 & 0,08 & 0,13 \\
4 & 47 & 5,05 & 0,07 & 0,11 \\
5 & 52,6 & 5,05 & 0,06 & 0,10 \\
6 & 82 & 5,05 & 0,05 & 0,06 \\
7 & 100 & 5,05 & 0,04 & 0,05 \\
8 & 180 & 5,05 & 0,02 & 0,03 \\
9 & 220 & 5,05 & 0,02 & 0,02 \\
10 & 302 & 5,05 & 0,01 & 0,02 \\
\hline
\end{tabular}

Berdasarkan data pada tabel 1 dapat dilihat bahwa current limiter dengan batas 0,25 A dengan tegangan input sebesar 5,05 VDC dapat bekerja dengan baik saat kondisi normal. Terdapat eror nilai arus terukur dan arus terhitung sebesar $0.01 \mathrm{~A}$. Berikut adalah grafik hubungan arus dengan besar beban resistor murni.

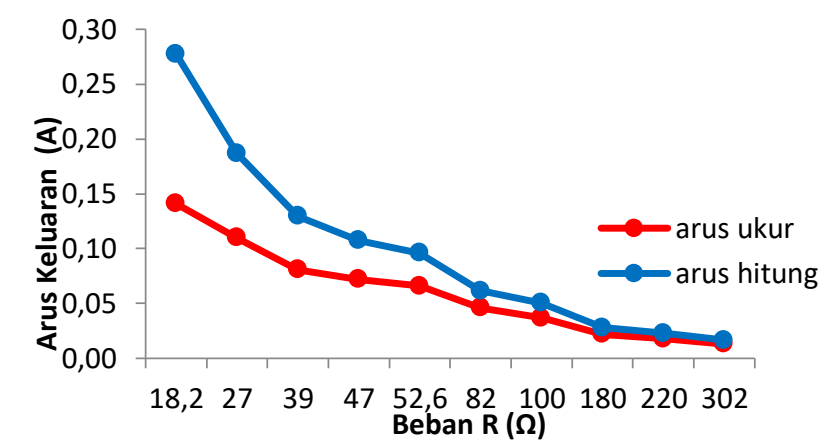

Gambar 4. Grafik hubungan arus dengan beban pada Current limiter batas $0,25 \mathrm{~A}$

Pada gambar 4 didapat bahwa current limiter dengan batas 0,25 A bekerja dengan baik dimana besar nilai arus beban berdasarkan besar beban resistor yang terpasang. Hal ini sudah sesuai dengan hukum ohm yaitu dengan nilai tegangan yang sama dan semakin besar nilai beban resistor maka semakin kecil arus yang mengalir melalui beban resistor tersebut.

Berikut data hasil pengujian Current limiter dengan batas 0,5 A dalam kondisi beban normal.

Tabel 2. Data Current limiter batas 0,5 A kondisi normal

\begin{tabular}{ccccc}
\hline \multirow{2}{*}{ No } & \multirow{2}{*}{ Beban $\mathrm{R}(\Omega)$} & Tegangan $(\mathrm{V})$ & lukur & Arus $(\mathrm{A})$ \\
& & & Ihitung \\
\hline 1 & 20,6 & 12,42 & 0,41 & 0,41 \\
2 & 27 & 12,42 & 0,35 & 0,35 \\
3 & 39 & 12,42 & 0,26 & 0,32 \\
4 & 47 & 12,42 & 0,21 & 0,26 \\
5 & 52,6 & 12,42 & 0,19 & 0,24 \\
6 & 82 & 12,42 & 0,12 & 0,15 \\
7 & 100 & 12,42 & 0,10 & 0,12 \\
8 & 180 & 12,42 & 0,06 & 0,07 \\
9 & 220 & 12,42 & 0,05 & 0,06 \\
10 & 302 & 12,42 & 0,04 & 0,04 \\
\hline
\end{tabular}

Berdasarkan data pada tabel 2 dapat diketahui bahwa current limiter dengan batas 0,5 A dengan tegangan input $12,42 \mathrm{~V}_{\mathrm{DC}}$ dapat bekerja dengan baik saat kondisi normal. Terdapat eror nilai arus terukur dan arus terhitung sebesar 0.02 A. Berikut adalah grafik hubungan arus dengan besar beban resistor murni.

Pada gambar 5 didapat bahwa current limiter dengan batas 0,5 A bekerja dengan baik dimana besar nilai arus beban berdasarkan besar beban resistor yang terpasang. Hal ini sudah sesuai dengan hukum ohm yaitu dengan nilai tegangan yang sama dan semakin besar nilai beban resistor 
maka semakin kecil arus yang mengalir melalui beban resistor tersebut [10].

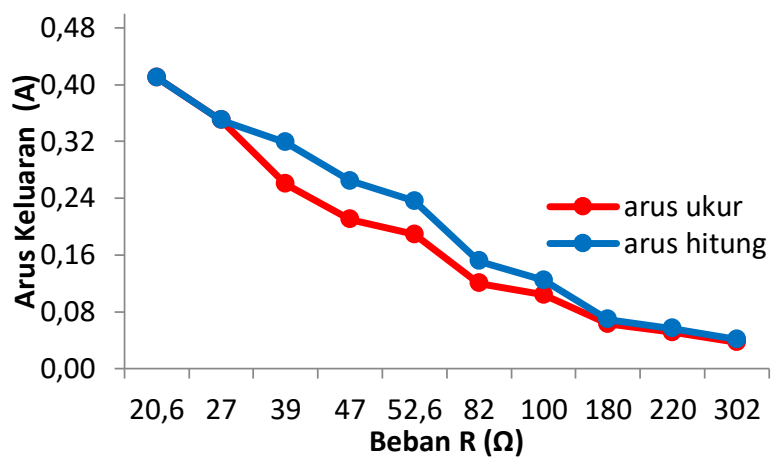

Gambar 5. Grafik hubungan arus dengan beban pada Current limiter batas 0,5 A

\subsection{Pengujian Arus Keluaran Kondisi Overcurrent}

Pada pengujian ini, data diambil dengan menggunakan beban berupa resistor murni yang memiliki nilai kurang dari $18 \Omega$ untuk current limiter beban $5 \mathrm{~V}_{\mathrm{DC}}$ dengan batas 0,25 A dan resistor murni dengan nilai kurang dari $20 \Omega$ untuk current limiter beban $12 \mathrm{~V}_{\mathrm{DC}}$ dengan batas $0,5 \mathrm{~A}$. Nilai arus keluaran current limiter diukur menggunakan multimeter DM-133D dengan probe arus dihubung seri dengan beban resistor murni. Berikut merupakan data yang diambil pada Current limiter dalam kondisi overcurrent.

Tabel 3. Data Current limiter batas 0,25 A kondisi overcurrent

\begin{tabular}{ccccc}
\hline No & Beban $R(\Omega)$ & Tegangan $(\mathrm{V})$ & lukur & $\begin{array}{c}\text { Arus }(\mathrm{A}) \\
\text { lukur tanpa current limit }\end{array}$ \\
\hline 1 & 1 & 5,05 & 0,22 & 5,05 \\
2 & 2,7 & 5,05 & 0,26 & 1,87 \\
3 & 3,7 & 5,05 & 0,26 & 1,36 \\
4 & 3,9 & 5,05 & 0,26 & 1,29 \\
5 & 4,7 & 5,05 & 0,26 & 1,07 \\
6 & 5,6 & 5,05 & 0,26 & 0,90 \\
7 & 8,2 & 5,05 & 0,21 & 0,62 \\
8 & 10 & 5,05 & 0,20 & 0,51 \\
9 & 12 & 5,05 & 0,19 & 0,42 \\
10 & 15 & 5,05 & 0,18 & 0,34 \\
\hline
\end{tabular}

Berdasarkan pada tabel 3 dapat dilihat bahwa rangkaian current limiter untuk beban 5 VDC saat kondisi overcurrent mampu membatasi arus sebesar 0,23 A. Terdapat eror sebesar 0.02 A pada arus limit yang dirancang dengan arus limit yang terukur. Hal ini disebabkan oleh resistor yang digunakan memiliki nilai toleransi. Nilai arus current limiter sudah sesuai dengan arus batas yang telah dirancang dengan kemampuan konverter arus searah tipe synchronous buck yaitu sebesar 0,3 A, ini membuktikan bahwa perhitungan komponen sudah sesuai dengan perancangan current limiter yang dibuat.
Berikut merupakan grafik Current limiter dengan batas $0,25 \mathrm{~A}$.

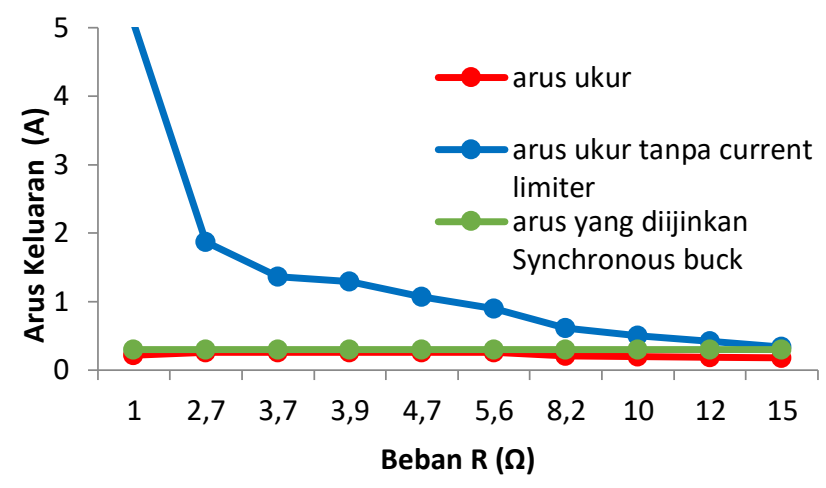

\section{Gambar 6. Grafik Current limiter 0,25 A}

Pada gambar 6 dapat diketahui bahwa arus hitung merupakan representasi dari arus beban yang sesungguhnya. Dari gambar grafik 6 dapat dilihat bahwa saat kondisi overcurrent yaitu variasi nilai beban resistor kurang dari $18 \Omega$, current limiter untuk beban 5 VDC mampu membatasi arus sebesar 0,23 A. Hal ini menunjukkan bahwa current limiter bekerja dengan baik dan sudah sesuai dengan batas yang dirancang yaitu sebesar 0,25 A sehingga mampu memproteksi konverter arus searah tipe synchronous buck saat terjadi overcurrent.

Berikut data hasil pengujian Current limiter dengan batas 0,5 A dalam kondisi beban overcurrent

Tabel 4. Data Current limiter batas 0,5 A kondisi overcurrent

\begin{tabular}{ccccc}
\hline No & Beban $R(\Omega)$ & Tegangan $(\mathrm{V})$ & lukur & $\begin{array}{c}\text { Arus }(\mathrm{A}) \\
\text { Iukur tanpa current limit }\end{array}$ \\
\hline 1 & 1 & 12,42 & 0,47 & 12,42 \\
2 & 2,7 & 12,42 & 0,46 & 4,60 \\
3 & 3,7 & 12,42 & 0,46 & 3,36 \\
4 & 3,9 & 12,42 & 0,46 & 3,18 \\
5 & 4,7 & 12,42 & 0,46 & 2,64 \\
6 & 5,6 & 12,42 & 0,46 & 2,22 \\
7 & 8,2 & 12,42 & 0,45 & 1,51 \\
8 & 10 & 12,42 & 0,44 & 1,24 \\
9 & 12 & 12,42 & 0,42 & 1,04 \\
10 & 15 & 12,42 & 0,43 & 0,83 \\
\hline
\end{tabular}

Berdasarkan pada tabel 4 dapat dilihat bahwa rangkaian current limiter untuk beban $12 \quad \mathrm{~V}_{\mathrm{DC}}$ saat kondisi overcurrent mampu membatasi arus sebesar 0,45 A. Terdapat eror sebesar 0.05 A pada arus limit yang dirancang dengan arus limit yang terukur. Hal ini disebabkan oleh resistor yang digunakan memiliki nilai toleransi. Nilai arus current limiter sudah sesuai dengan arus batas yang telah dirancang dengan kemampuan baterai serta perangkat yang terhubung dengan baterai yaitu sebesar 0,5 A, ini membuktikan bahwa perhitungan komponen sudah sesuai dengan perancangan current limiter yang dibuat. 
Berikut merupakan grafik current limiter dengan batas 0,5 A.

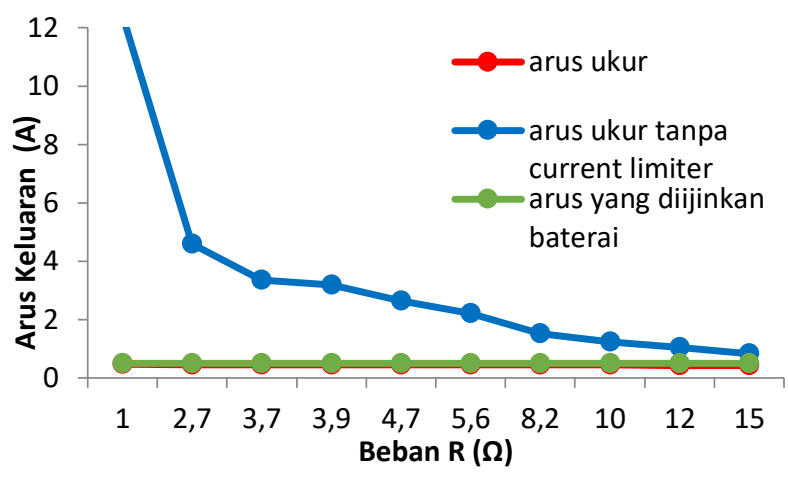

Gambar 7. Grafik Current limiter 0,5 A

Pada gambar 7 dapat diketahui bahwa arus hitung merupakan representasi dari arus beban yang sesungguhnya. Dari gambar grafik 7 dapat dilihat bahwa saat kondisi overcurrent yaitu variasi nilai beban resistor kurang dari $20 \Omega$, current limiter untuk beban $12 \mathrm{~V}_{\mathrm{DC}}$ mampu membatasi arus sebesar 0,45 A. Hal ini menunjukkan bahwa current limiter bekerja dengan baik dan sudah sesuai dengan batas yang dirancang yaitu sebesar 0,5 A sehingga mampu memproteksi baterai serta perangkat lain yang terhubung dengan baterai saat terjadi overcurrent

\subsection{Pengujian Arus Keluaran Hubung Singkat}

Pada pengujian ini, sistem Hybrid Charger Controller dalam kondisi bekerja dimana semua perangkat konverter arus searah pada sistem Hybrid Charger Controller terhubung pada catudaya baterai, sedangkan pada sisi beban $5 \quad \mathrm{~V}_{\mathrm{DC}}$ dan $12 \quad \mathrm{~V}_{\mathrm{DC}}$ dipasang jumper yang dihubungkan sisi positif dan negatifnya sehingga rangkaian current limiter menjadi short circuit.

Berikut merupakan gambar Current limiter 0,25 A saat diuji short circuit.

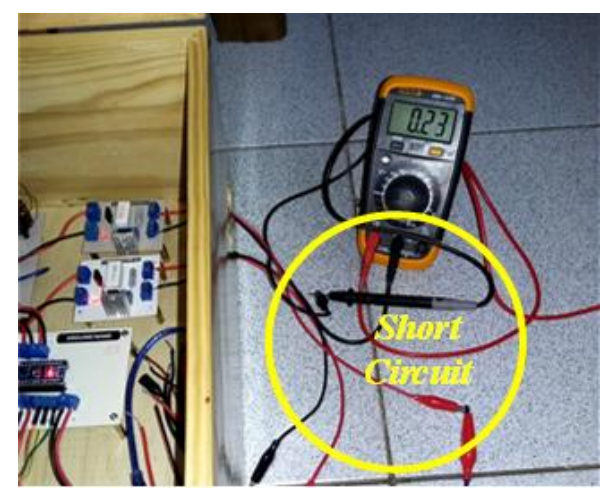

Gambar 8. Data Current limiter batas 0,25 A kondisi hubung singkat
Pada gambar 8 dengan tegangan input sebesar 5,05 $\mathrm{V}_{\mathrm{DC}}$ saat rangkaian current limiter dalam kondisi short circuit arus keluaran current limiter terukur sebesar 0,23A. Besar arus yang terukur pada current limiter sesuai dengan besar batas arus yang telah dirancang untuk beban $5 \mathrm{~V}_{\text {DC }}$ yaitu sebesar 0,25 A. Hal ini menunjukkan bahwa current limiter dapat bekerja saat terjadi hubung singkat sehingga dapat mencegah kerusakan perangkat konverter arus searah tipe synchronous buck akibat arus hubung singkat.

Berikut merupakan gambar data current limiter 0,5 A saat kondisi hubung singkat

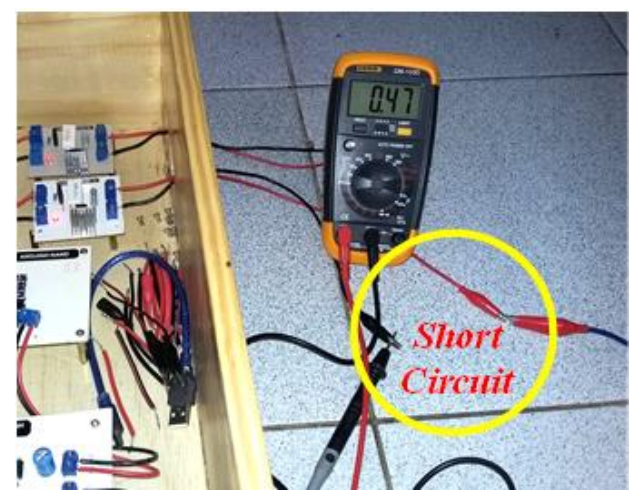

Gambar 9. Data Current limiter batas 0,5A kondisi hubung singkat

Pada gambar 9 dengan tegangan Input sebesar 12,42 $\mathrm{V}_{\mathrm{DC}}$ saat rangkaian current limiter dalam kondisi short circuit arus keluaran current limiter terukur sebesar $0.47 \mathrm{~A}$. Besar arus yang terukur pada current limiter sesuai dengan besar batas arus yang telah dirancang untuk beban $12 \mathrm{~V}_{\text {DC }}$ yaitu sebesar 0,5 A. Hal ini menunjukkan bahwa current limiter dapat bekerja saat terjadi hubung singkat sehingga dapat mencegah kerusakan baterai serta perangkat lain yang terhubung dengan baterai akibat arus hubung singkat.

\section{Kesimpulan}

Rangkaian current limiter telah berhasil dibuat yaitu untuk beban $5 \mathrm{~V}_{\mathrm{DC}}$ batas $0,25 \mathrm{~A}$ dan beban $12 \mathrm{~V}_{\mathrm{DC}}$ batas 0,5 A.Pada pengujian kondisi normal dengan nilai resistor lebih dari $16 \Omega$ untuk current limiter batas 0,25 A dan nilai resistor lebih dari $20 \Omega$ untuk current limiter dengan batas 0,5 A, arus keluaran current limiter memiliki besar nilai berdasarkan nilai beban resistor $(\Omega)$ yaitu semakin besar nilai resistor maka arusnya akan semakin kecil. sesuai dengan perhitungan menggunakan hukum ohm dengan eror 0,01 A untuk current limiter 0,25 A dan eror sebesar 0.02 A untuk current limiter 0,5 A.Pada pengujian kondisi overcurrent dengan nilai beban resitor lebih kecil dari beban resistor saat kondisi normal yaitu kurang dari $18 \Omega$ untuk current limiter beban $5 \mathrm{~V}_{\mathrm{DC}}$ batas $0,25 \mathrm{~A}$ dan kurang dari $20 \Omega$ untuk current limiter beban $12 \mathrm{~V}_{\mathrm{DC}}$ batas $0,5 \mathrm{~A}$, besar arus keluaran current limiter untuk beban $5 \mathrm{~V}_{\mathrm{DC}}$ sebesar 0,23 A dengan eror sebesar 0.02 A dan untuk 
current limiter untuk beban $12 \mathrm{~V}_{\mathrm{DC}}$ memiliki nilai arus keluaran sebesar $0.45 \mathrm{~A}$ dengan eror sebesar $0.05 \mathrm{~A}$. Arus keluaran current limiter sudah sesuai dengan batas arus yang di rancang sesuai kemampuan konverter synchronous buck dan baterai serta perangkat yang terhubung dalam menahan arus. Pada pengujian kondisi hubung singkat besar nilai current limiter sesuai dengan batas yang telah dirancang yaitu sebesar 0,23 A dan 0.47 A. Sehingga current limiter mampu melindungi perangkat keras synchronous buck serta baterai dan perangkat lainnya yang terhubung dengan baterai saat terjadi hubung singkat.

\section{Referensi}

[1] A. Karim and W. Hasbi, Rancang Bangun Sistem Adjustable Electronic Fuse Untuk Platform Microsatellite ( Adjustable Electronic Fuse System Design For Microsatellite Platform ), pp. 73-81.

[2] Muterspaugh, Max W. Dual Voltage Regulator With Foldback Current Limiting. United States Patent 5,578,916. 26 November 1996.

[3] Nesler, John J. Overcurrent limiter Circuit For Switching Regulator Power Supplies. Los Angeles Paten 4,428,015. 24 January 1984.
[4] D. A. C. G.G. Liversidge, K.C. Cundy, J.F. Bishop, "United States Patent (19) 54," vol. 96, no. 19, pp. 62-66, 1980.

[5] Lombardi, Carl A. Current Limiter Circuit. Los United States Patent 3,521,087. 21 Juli 1970.

[6] J. Badham, Short Circuit, Book, 1986.

[7] H. D. Surjono and D. Ph, .Elektronika: Teori dan Penerapan. Jember,Jawa Timur : Penerbit Cerdas Ulet Kreatif, 2007.

[8] J. Ahmad, "Elektronika Dasar 1," Elektron. Dasar 1, pp. 1-68, 2007.

[9] Malvino, Albert and David Bates. Electronic Principles. United States of America: McGraw-Hill Education, 2016

[10] R. C. Dorf, The electrical engineering handbook. 2000.

[11] N. Sclater and E. J. Traister, Handbook of Electrical Design Details. 2003.

[12] Fairchild Semiconductor. "BD135/137/139 NPN Epitaxial Silicon Transistor." Fairchild Semiconductor Corporation. Agustus 2013. www.fairchildsemi.com (diakses maret 2018). 